\title{
Ciclos de Desenvolvimento Humano e Formação de Educadores
}

Miguel G. Arroyo

\begin{abstract}
RESUMO: Os ciclos não são mais uma proposta isolada de algumas escolas, a nova LDB os legitimou e estão sendo adotados por muitas redes escolares. Este texto se pergunta pelo tipo de profissional que está sendo formado nessa modalidade de organização do trabalho pedagógico. A reflexão está estruturada em duas partes. A primeira reflete sobre o caráter formador do repensar das concepções e práticas de formação que acontecem na implantação dos ciclos. A segunda parte reflete sobre as virtualidades formadoras de todo o processo de desconstrução de uma estrutura centrada nas Temporalidades ou Ciclos do Desenvolvimento Humano.
\end{abstract}

Palavras-chave: Ciclos, formação de professores, organização escolar, educação básica

A organização da escola em ciclos está se tornando uma realidade em numerosas redes municipais e estaduais e no Distrito Federal. Milhares de professores ${ }^{1}$, de dirigentes e técnicos estão empenhados na implantação dos ciclos. A nova LDB incorporou essa modalidade de organização da educação básica no art. 23, conseqüentemente os ciclos não são mais uma proposta inovadora isolada de algumas escolas ou redes, trata-se de uma forma de organizar os processos educativos que

\footnotetext{
* Professor titular na Faculdade de Educação da Universidade Federal de Minas Gerais (UFMG). Email: arroyo@goldenlink.com.br
} 
está merecendo a devida atenção dos formuladores de políticas e de currículos, de administradores e de formadores. Por que tanta tensão e curiosidade?

Observo que a atenção por parte dos professores se deve em grande parte a uma sensação de ameaça. Estamos tão acostumados com a organização seriada que ela passou a fazer parte de nosso imaginário escolar. Desde criancinhas nos levaram às primeiras séries, fizemos o curso-percurso subindo por andares, por séries ou fomos retidos e tentamos de novo subir essas rampas tão escorregadias. Formamo-nos professores regentes das primeiras séries, licenciados de séries avançadas. Lecionamos por anos na estrutura seriada, na organização gradeada e disciplinar do trabalho. Para o sistema seriado fomos formados e ele terminou nos formando e deformando. Trazemos suas marcas em nossa pele, em nossa cultura profissional. Desconstruir a organização seriada e sua lógica é desconstruir um pedaço de nós. Os ciclos ameaçam nossa auto-imagem.

Toda nova organização do trabalho educativo traz conseqüências sérias em todos os níveis, sobretudo em nossa auto-imagem profissional. As pesquisas e a reflexão teórica voltam-se para as propostas pedagógicas que estão implementando os ciclos. A formação de profissionais da educação básica se pergunta pelo tipo de profissional que está sendo requerido, ou melhor, que está se formando nessa modalidade de organização do trabalho pedagógico. Nessas preocupações situo minha reflexão, tendo como referência o convívio direto com profissionais que estão implantando os Ciclos de Desenvolvimento Humano.

Nos seminários e congressos de professores, nos encontros com dirigentes municipais e estaduais sempre nos colocam as mesmas questões: como nos preparar para trabalhar com ciclos? Quanto tempo dedicamos à preparação, que cursos oferecemos, que competências prévias desenvolvemos, como avaliamos se os profissionais estão prontos para iniciar a organização dos ciclos?

Essas questões refletem uma determinada concepção e prática de formação, muito arraigada na nossa tradição pedagógica, na formulação de políticas e até na orientação ou filosofia dos cursos de formação e qualificação. Nas propostas pedagógicas que acompanho e que tem como um dos objetivos organizar os processos de trabalho em ciclos, a questão da formação de educadores tem centralidade. Várias administrações criaram ou dinamizaram centros de aperfeiçoamento de seus pro- 
fissionais e mantêm um diálogo estreito com as escolas Normais e cursos de pedagogia e licenciatura. Diríamos que as experiências de ciclo vêm sendo um campo fecundo para repensar concepções e práticas de formação de educadores. Essa é uma das questões que trabalho neste texto.

Há um outro tipo de questão que aflora na prática: em que sentido podemos dizer que os professores e as professoras estão se formando como novos profissionais na medida em que participam da reestruturação do sistema escolar, de sua lógica seriada e se inserem em um processo de construir outra lógica estruturante de seu trabalho? Pretendo neste texto refletir sobre os aprendizados que estamos fazendo, os questionamentos que afloram, a maneira como os próprios educadores se defrontam com sua formação e sua qualificação, inserindo-se em coletivos de profissionais de ciclos. A prática pode reforçar velhas concepções, mas pode também questioná-las e, dependendo da natureza das práticas, pode formar novos sujeitos, novos profissionais.

Divido meu texto em duas partes, na primeira aponto como a organização do trabalho em Ciclos de Desenvolvimento Humano nos leva a questionar e superar determinadas concepções e práticas de formação e qualificação, o que provoca um processo formador. Na segunda parte reflito sobre as virtualidades formadoras de todo o percurso de desconstrução da estrutura seriada e de construção de uma estrutura centrada nas temporalidades ou nos Ciclos do Desenvolvimento Humano.

\section{Questionando a concepção precedente de formação}

Faz parte do pensar mais tradicional que a qualificação dos profissionais se coloque como um pré-requisito e uma precondição à implantação de mudanças na escola. Daí a pergunta que sempre nos é feita: quanto tempo demoramos na preparação para a intervenção? Faz parte de nossa tradição. Se pretendemos introduzir uma nova prática, nova metodologia, um novo currículo ou uma nova organização escolar, a primeira questão a colocarmos seria quem vai dar conta das inovações e como preparar, capacitar os professores para as novas tarefas.

O caráter antecedente de toda qualificação é aceito como algo inquestionável, não apenas quando pensamos na formação de profes- 
sores, como também quando estes pensam na educação de seus alunos. Qual o sentido do tempo de escola? Ser o tempo antecedente, precedente à vida adulta, à vida profissional. Aceitamos que ao tempo de fazer terá de preceder o tempo de aprender a fazer. Ao tempo de intervir, terá de preceder o tempo de aprender, de qualificar-se para intervir com qualidade. Sempre nos disseram que o domínio da teoria precede à prática.

Essa concepção de educação precedente polariza a vida em dois tempos: de aprender e de fazer, de formação e de ação. Polariza a teoria e a prática, o pensar e o fazer, o trabalho intelectual e o manual. Polariza e separa as minorias pensantes e as maiorias apenas ativas. Essa mesma concepção tem inspirado o pensar a formação e a qualificação de professores. Tem marcado as políticas e os currículos.

Quando se critica a escola básica afirmando ser de má qualidade, logo se pensa em treinar seus profissionais. Se a prática é de má qualidade só há uma explicação, a má qualidade no preparo dos mestres. Essa lógica mecânica justifica que todo governo e toda agência financiadora coloquem como prioridade qualificar e requalificar, treinar e retreinar os professores. É dominante a idéia de que toda inovação ou melhoria educativa deve ser precedida de um tempo longo e caro de preparo daqueles que vão implementá-la. Ninguém ouse dirigir carro nesse trânsito urbano maluco sem antes aprender as leis de trânsito, treinar-se em longas horas de auto-escola, passar na prova e obter carteira de habilitação. Essa semelhança está tão internalizada em nosso pensamento pedagógico que passamos meses e anos requalificando, gastamos tempo, dinheiro e energias treinando para a intervenção sempre adiada por falta de preparo adequado.

$\mathrm{Na}$ organização dos ciclos não seguimos essa visão precedente de formação. Na medida em que vamos construindo propostas inovadoras, em que a organização dos ciclos entra como uma das inovações centrais, fomos questionando essa concepção e essa prática de formação. Fomos questionando o papel dos cursos e dos centros de aperfeiçoamento. Não separamos a equipe de coordenação pedagógica para planejar ações e a equipe de qualificação para previamente dar cursos. Não apenas porque essa visão polariza os tempos de pensar e fazer, de teoria e de prática, os tempos de formação e de ação-intervenção, mas por algo muito sério, ela carrega uma concepção de educador que prioriza domínios e competências pontuais. Se se pretende inovar métodos, na visão tradicional, se propõe treinar no domínio de novos métodos. Se se pretende organizar a escola em ciclos, na visão tradicional, 
se propõe que aprendam primeiro o que é ciclo, conteúdos de ciclos, avaliação de ciclo, passagem ou retenção no ciclo etc. Nessa visão tradicional, o profissional da educação básica é visto como alguém competente em tarefas, um tarefeiro. Competente em práticas, um prático. A experiência nos levou a perguntar se quando as tarefas mudam o professor de educação básica muda. Se quando mudam suas competências, muda seu papel social e cultural. Será que a cada inovação de conteúdo, método ou organização mudará o papel social da educação, da escola e o papel e a função social e cultural dos educadores? Defrontando-nos com tais questões, vamos desconstruindo a visão precedente. Uma tarefa de formação.

A visão tradicional parece supor que nosso papel muda em cada conjuntura, o que reflete uma visão pobre da educação básica e dos educadores. Reflete os estragos que a visão tecnicista fez na concepção de educação básica e na figura social de seus profissionais e de sua formação. Reflete, ainda, os estragos ocasionados por ela nas políticas de formação, nos currículos, nos cursos e nas instituições formadoras. A visão tecnicista, utilitária e mercantil desqualificou a educação básica, o papel de seus profissionais e os processos de sua formação, marginalizou o que há de mais permanente - as dimensões históricas que a função de educador acumulou como tarefa social e cultural, como ofício. Desqualificadas e ignoradas essas dimensões e funções mais permanentes e históricas, reduziu a educação ao ensino, à transmissão de informações, ao treinamento de competências demandadas em cada conjuntura de mercado. Desqualificou o próprio ofício de mestres.

O perfil de profissional que restou é esse que estamos formando ou deformando nas últimas décadas. Todos que temos experiência em cursos de magistério, de licenciatura, de habilitações em administração, supervisão e orientação, temos experimentado, com pesar, como é difícil pensar nas dimensões mais permanentes do ofício de mestres, de educadores, como é difícil ler e debater sobre essas dimensões, como os futuros professores, diretores, supervisores preferem saber o como e o que fazer, diante do novo currículo, da nova metodologia e da nova organização. Os futuros profissionais da escola e aqueles que nela trabaIham internalizaram a concepção precedente: só interessa aprender o que os prepare para tarefas concretas, para intervenções pontuais. A estrutura de muitos currículos dos cursos de formação e de qualificação ainda mantém essa lógica precedente. Muitos, entretanto, tentam superá-la. As propostas inovadoras que acompanho também tentam. Veremos como. 
O que pretendo destacar é que o questionamento dessa concepção precedente de formação, a tarefeira, pode ser um tempo de qualificação. Um tempo a ser explorado pedagogicamente, redefinindo imagens de formação e sobretudo auto-imagens de professor qualificado. Pode ser um tempo propício para redefinir até preconceitos que existem no interior da categoria. Lembro-me que em um dos debates uma professora ponderou:

Agora entendo melhor porque somos divididos em categorias, não pelo que fazemos, nem pela competência que temos, mas pela formação precedente e pela titulação. As professoras $\mathrm{P} 1$ somos consideradas de segunda categoria, sem prestígio, com piores salários e com menores possibilidades de avançar na carreira, apenas porque somos diferentes na titulação, ainda que sejamos tão competentes na qualificação adquirida no trabalho.

De fato, a centralidade dada à formação precedente condiciona o ser profissional. Equacioná-la devidamente pode nos ajudar a superar preconceitos. Pensemos em outras questões levantadas e que preocupam os professores.

\section{Como definir o perfil de educador?}

Outra questão que nos é colocada com freqüência quando apresentamos a organização por ciclos: como definir as competências, as incumbências, o perfil de professor que dará conta da organização escolar por ciclos? Antes de organizar os cursos, é definido esse perfil? Que cursos, matérias, carga horária são necessários?

No processo de elaboração e implementação das propostas pedagógicas nas redes municipais e estaduais e no Distrito Federal também surgiram essas preocupações. Cada profissional parecia perguntar-se: que profissional devo ser agora? Que competências devo dominar para dar conta da minha turma, do meu ciclo, da nova organização escolar?

A maneira mais tradicional de responder a essa questão seria a seguinte: se a nova LDB no seu art. 23 sugere que o sistema escolar seja organizado em ciclos, que profissional ela propõe para dar conta dessa nova 
organização escolar? A própria LDB define as competências necessárias e as condições para a implantação dos ciclos? Existe algum parecer oficial, alguma resolução que defina essas competências e essas condições? Com base nesse levantamento, poderíamos equacionar os cursos de formação e requalificação necessários para termos profissionais capacitados para implementar a nova organização escolar. Seguindo nossa tradição, deveríamos esperar que algum parecer dos conselhos listasse as competências a serem formadas e até definisse a carga horária, as matérias, o número de alunos por turma, se devemos reter no meio ou no final do ciclo... Toda inovação deveria ser decretada, tutelada, regulamentada, autorizada.

Rotulo de tradicional essa forma de pensar a formação de profissionais da educação básica porque é com essa lógica que temos equacionado em nossa tradição pedagógica as políticas de formação, os currículos e as competências requeridas dos mestres. Estes aparecem como super-heróis que em cada conjuntura, em cada cena do filme, tem de dar conta das novas competências, dos novos conhecimentos, conteúdos e técnicas, das incumbências (termo comum usado nos pareceres oficiais dos conselhos) que lhes são atribuídas pelas leis, pelas reformas curriculares, pelas políticas oficiais, ou, como agora se diz, demandadas pelos avanços da sociedade do conhecimento, da informática e das tecnologias. Nessa lógica, pensar nos currículos e nos cursos de formação será readaptá-los ao sempre inconcluso propósito de preparar os mestressuper-heróis da escola, capacitá-los para dar conta do novo filme, das novas (sempre novas e tão velhas!) "incumbências atribuídas pela lei".

As propostas pedagógicas que acompanho e que estão organizando a escola em Ciclos de Desenvolvimento Humano não têm seguido essa lógica na formação de professores, ao contrário, tentam superá-la. Do processo de superação procuramos fazer um tempo de re-qualificação. $\mathrm{Na}$ medida em que avançamos na implantação dos ciclos, percebemos que não é esse o melhor caminho para definir o perfil do educador. Que lógica tradicional é essa? Ajuda-nos a equacionar o profissional que vem se formando no processo de organização da prática educativa em ciclos? Entender bem essa lógica tradicional é importante para não cair nela, para superá-la. É uma lógica dedutiva. Temos de reconhecer que tal lógica vem nos colocando por décadas no mesmo beco sem saída.

O grave é que gestores de políticas e pareceres de dignos conseIheiros continuam presos a essa lógica dedutiva. Os primeiros parágrafos dos pareceres iniciarão lembrando que a nova legislação educacional brasileira corporificada nos estatutos legais (enumeram-se os esta- 
tutos legais) atribui aos professores de educação básica tais incumbências (enumeram-se com detalhes). Conseqüentemente, conclui-se que a formação de um profissional capaz de exercer plenamente e com a devida competência as atribuições que Ihe foram legalmente conferidas deverá seguir tal currículo, com determinada carga horária, em determinados níveis e centros de formação, ou que ele deverá freqüentar tais cursos de requalificação. Cumpridos os dignos pareceres, só nos resta esperar no fim da linha, e os centros de formação lançarão no mercado a cada ano, em solenes formaturas, os profissionais que a sociedade e a escola esperam e que as leis e políticas decretaram.

Como lógica parecerista, perfeita, porém distante da lógica social. Por quê? Esse pensar dedutivo parece supor que os estatutos legais, as políticas, as normas criam a realidade social, que os papéis e as funções sociais podem ser definidos e modificados com políticas e normas, a cada demanda, em cada conjuntura histórica como o mocinho muda de papel em cada cena do filme, dependendo do script definido. Parece supor ainda que propondo um script novo, uma nova forma ou formato curricular e colocando a massa informe dos formandos e treinandos nesse formato formaremos novos papéis sociais para novas práticas. Insisto, não se implantarão propostas inovadoras listando o que queremos inovar, listando as competências que os educadores devem aprender e montando cursos de treinamento para formá-los. Uma vez formados, teremos novos profissionais inovadores e poderemos iniciar tranqüilos as propostas? Uma visão ingênua que ao longo das experiências vamos redefinindo e superando.

Esse sonho de criar novos papéis sociais atribuindo incumbências, propondo formatos, é muito antigo. Quantos manuais desde o Medievo e o Renascimento se propuseram a formar o bom menino, o perfeito monge, o heróico militar, o digno príncipe, a perfeita casada e até o bom selvagem? Pouco sabemos da eficácia desses manuais na conformação de crianças, de monges, de militares, de príncipes, de casados e de casadas e de bons selvagens. Faz muito tempo que esses manuais saíram de moda e a crença de que é por aí que se conformam papéis sociais, também. Por que manter essa crença quando pensamos na formação de professores?

Poderíamos fazer pesquisas históricas para entender porque apenas quando pensamos e decidimos sobre o ofício dos mestres da educação básica mantemos esse pensamento tão ingênuo. Será porque identificamos tanto as professoras com a infância que terminamos por infantilizá-las ou tratá-las como crianças, sempre inacabadas? Será porque a maioria são professoras, mulheres? Haveria um viés de gênero? Sobre a formação de 
outros papéis sociais não temos essa postura, nem sequer em relação aos professores de educação superior, e menos ainda em relação aos médicos, advogados, engenheiros... Deixamos que esses papéis se conformem na dinâmica social após titulados ou diplomados.

Avançando na implantação dos Ciclos de Desenvolvimento Humano, essa lógica dedutiva e essa ingênua pretensão de redefinir os papéis de profissionais da educação básica vão ficando mais desencontrados com o sentido das propostas pedagógicas. Na medida em que outro profissional vai se explicitando, percebemos o que há de mais permanente no ofício de mestre. A experiência de reorganizar a estrutura escolar nos defronta com velhos papéis sociais e culturais. Os professores se reencontram com outras identidades. Isso é formador.

É curioso constatar que é no campo da formação de profissionais de educação básica onde mais abundam as leis e os pareceres de conselhos, os palpites fáceis de cada novo governante, das equipes técnicas, e até de agências de financiamento, nacionais e internacionais. Na formação de profissionais do magistério superior, ou para as áreas de saúde, engenharia, direito, arquitetura, não se adota a mesma lógica dedutiva, nem se prescrevem e modificam com tanta facilidade as atribuições e incumbências por meio de leis e pareceres. É outro olhar sobre a construção histórica desses papéis sociais. Os próprios profissionais, suas corporações, suas organizações representativas têm peso, são guardiões de seu ofício, de seu ethos, de sua qualidade e sua identidade. Participam na definição de sua qualificação e colaboram. Essa história vem de longe e é respeitada. Uma história bem diferente do trato dado à formação de professores de educação básica, do trato dado ao ofício tão antigo, mais do que esses outros ofícios, de educar crianças, adolescentes e jovens. A forma como esse ofício é tratado nas políticas é como se fosse um fazer e pensar indefinido, deformado. Cada governante, legislador ou conselheiro, cada tecnocrata de banco se julga no direito de conformá-lo à mercê de cada demanda conjuntural.

Não é ingênuo pensar que as atribuições listadas em cada nova lei, nova política, novo parecer possam, por um passe de mágica, alterar o histórico ofício de mestre que os professores repetem? É curioso com que facilidade cada lei ou parecer lista novas atribuições com a pretensão de formar um novo perfil, mais moderno e atualizado de educador. O grave não é, apenas, essa ingênua pretensão. $O$ grave é confundir a função histórica de educador com detalhes, com capacidades de elaborar o projeto de escola, por exemplo, ou com aprender as técnicas 
de condução de uma reunião com as famílias, ou aprender novos critérios de enturmação, de avaliação, de aceleração. É grave porque distraídas as leis e os pareceres com detalhes, os currículos, as pesquisas e as políticas de formação não chegam ao cerne do ofício de mestres, do papel social de educador, do que é a qualidade constitutiva, do que é historicamente identitário do pensar e agir educativos. É isso que deve ser formado e qualificado. Outra concepção e outra prática de formação.

\section{Opermanente no ofício de mestre}

As propostas pedagógicas que acompanho não equacionam a formação e a qualificação dos professores segundo essa lógica tradicional. Ao contrário, pretende-se superá-la. Partimos de outro olhar, de outra concepção do ofício de mestre, do educador, do sempre velho e sempre novo papel de pedagogo. A hipótese que nos orienta é a de que os profissionais da educação básica estão mais feitos do que essa lógica dedutiva supõe; de que a melhor estratégia é partir da formação que eles já têm, assumir que a função de educador carrega dimensões definidas socialmente, partir do que há de permanente nesses velhos papéis sociais. É outra lógica para a formação dos profissionais da educação básica.

O ofício de mestre é anterior à escola e nela se reproduz. Foi se conformando ao longo da história, acompanhando os lentos processos de desenvolvimento humano, os processos civilizatórios e educativos, as tensões sociais, culturais e políticas. De lá vêm nossos mestres ancestrais. Sua configuração social e cultural situa-se nos tempos de longa duração. Cada educador dificilmente consegue fugir de ethos, estilos, culturas, práticas, identidades que têm uma longa história. O ofício de mestre, inclusive mestre-escola, se confundiu e ainda se confunde com outros ofícios próximos, presentes em todas as culturas. Os sempre presentes condutores da infância, os pedagogos, os iniciadores nas culturas, nos saberes, valores, métodos e crenças. Os socializadores, formadores de hábitos e condutas, sistematizadores do conhecimento.

Funções sociais e culturais que permanecem tão parecidas, tão constantes, herdando saberes e técnicas, por vezes resistindo a atribuições legais, a rotinas burocráticas. Resistindo porque sua formação histórica se materializou em práticas, símbolos em tecidos e tramas, em complexas redes sociais e escolares por onde passa a construção do conhecimento e da cultura. 
Em vão pretender alterar com pareceres, com listagem de atribuições e incumbências um ofício tão definido historicamente, tão parecido em todas as culturas e em todas as instituições educativas. Um ofício tornado público, situado no campo dos direitos. Quem não constatou que todas as escolas são tão próximas em lugares tão distantes, em formações sociais tão diversas? Os tecidos do desenvolvimento humano, da cultura e do conhecimento são tão próximos! E o ofício de mestre também.

Penso que uma das tarefas urgentes das pesquisas e análises, das políticas e dos currículos de formação é superar a visão tradicional e avançar em outro olhar que leve as pesquisas, teorias, políticas e currículos na direção do que há de mais constante, mais permanente no velho e sempre novo ofício de educar, de humanizar, de formar as mentes, os valores, os hábitos, as identidades, de produzir e aprender o conhecimento. Não é essa a função social e cultural da educação básica e de seus mestres? Não é esse o subsolo, tão denso quanto tenso, no qual sempre se situou o ofício de mestre, a função pedagógica?

Situados nessa perspectiva, podemos equacionar a formação dos professores para a implantação dos Ciclos de Desenvolvimento Humano, tentando explorar as proximidades existentes entre o que é constitutivo do ofício de mestre, as velhas e renovadas funções educativas, o permanente em toda ação cultural e educativa. Como? Tentando aproximar a concepção de ciclo dos estreitos e históricos vínculos entre educação, formação e desenvolvimento humano.

$\mathrm{Na}$ medida em que a organização da escola e do sistema escolar vai sendo questionada, percebemos que sua estrutura, as séries, as grades, as disciplinas, a organização dos tempos, espaços e do trabalho materializam uma determinada concepção de educação básica e de seu profissional, conseqüentemente exigem capacidades adequadas a essa estrutura. Levados por esse caminhar nos defrontamos com as grandes questões e as permanentes dimensões da formação dos educadores, da configuração de seu papel social e cultural.

$\mathrm{Na}$ implantação das propostas pedagógicas que se empenham em organizar a escola por ciclos, percebemos que é reforçado o que há de mais permanente na função social e cultural dos profissionais da educação. Não se trata de acrescentar novas incumbências a serem treinadas previamente, mas de criar situações coletivas que propiciem explicitar e cultivar o papel, os valores e saberes educativos que cada educador já põe em ação em sua prática, nas escolhas que faz cada dia no trato com 
os educandos. Preferimos nos basear no acúmulo de saberes, pensamentos e valores que informam o que há de mais educativo no ofício de mestres, que todos cultivam na diversidade de práticas, de culturas e identidades de cada um.

Cada professor, os coletivos de profissionais carregam cada dia para a escola uma imagem de educador que não inventam, nem aprenderam apenas nos cursos de formação e treinamento. É sua imagem social, é seu papel cultural, são formas de se relacionar como adultos com crianças, adolescentes ou jovens. São aprendizados feitos em outros papéis sociais: no convívio e no cuidado com irmãos e irmãs, nos papéis de parentes, avós, pais e mães, no aprendizado feito nos grupos de idade, nas amizades, nos movimentos sociais, nas organizações da categoria, nas experiências escolares, nas relações dos tempos de formação, no aprendizado de ser criança, adolescente, jovem e adulto. A nova LDB em seu art. $1^{\circ}$ coloca a educação e a formação nessa pluralidade de vivências sociais e culturais, de aprendizados. Fomos acumulando saberes, valores, formas de diálogo, de relações, de intercâmbios que levamos para o que há de mais permanente e definidor de toda ação educativa: ser uma relação, um diálogo de pessoas, de sujeitos sociais, culturais, de gerações. $\mathrm{Na}$ prática educativa socializamos os aprendizados que fizemos e fazemos, que a sociedade acumulou, que nós acumulamos como indivíduos e como coletivo.

Organizar os processos educativos em Ciclos de Desenvolvimento Humano ou tendo como eixo o desenvolvimento humano, suas temporalidades, nos situa ou ressitua nessas dimensões mais permanentes do fazer educativo, do ofício de educadores. Conseqüentemente, não se trata de acrescentar novas competências a serem previamente treinadas, mas de voltar o olhar dos mestres para essas dimensões, para esse lastro de competências, de saberes e valores acumulados e freqüentemente marginalizados e ignorados nos programas de qualificação. Diríamos que o melhor processo de formação é explicitar, trazer à tona essas dimensões permanentes soterradas sob os escombros e o entulho burocrático, rotineiro de atribuições acidentais. Trata-se de inverter prioridades. Priorizar as dimensões constitutivas do ofício de mestres, secundarizar o que soterrou essas dimensões. Deixar que aflore e seja assumido o educador que há em cada profissional da escola, que seja assumida a qualificação que carrega cada coletivo de professores. Criar um clima propício ao reencontro com sua identidade, com os saberes coletivos que vêm de longe e que foram aprendidos em múltiplas relações humanas e educativas. Trabalhar as competências 
coletivas nas práticas em que se expressam. Por aí nos afastamos da estreita, antecedente e treinadora concepção de formação e qualificação. Afastamo-nos de uma concepção pontual, conjuntural de qualificação e do ofício de educador, sempre incerto, mutável, à mercê da última lei, da última reforma, do ultimo currículo ou didática.

O complexo processo histórico de construção de papéis sociais, do papel de pedagogo, educador ou mestre não se altera com normas, políticas, intervenções pontuais. Estas passam e com elas passa a ilusão de gestores e teóricos. As dimensões configuradas lentamente para ofícios que fazem parte de uma longa história de humanização e formação humana permanecem. É aí que pretendemos amarrar a qualificação dos educadores.

O que estou sugerindo é que a tentativa de organizar o sistema escolar por Ciclos de Desenvolvimento Humano nos foi levando a descobrir e mexer nas dimensões mais constitutivas do ofício de mestres, e não apenas em novas atribuições e incumbências. Em outros termos, dependendo do patamar em que coloquemos a organização por ciclos, poderemos estar tocando níveis mais superficiais ou mais profundos da escola e do perfil de educador.

Chegamos a um ponto importante para equacionar a formação de professores e a organização dos ciclos. A questão que se coloca é se a organização dos ciclos nos leva ou não ao encontro dessas questões de fundo, se tocamos na visão de educação básica, do papel social e cultural de seus profissionais, ou a concepção de ciclos que em muitas redes está sendo implantada nos deixa na periferia, na epiderme dessas questões de fundo, nos desvia dessas questões para nos preocupar apenas com competências pontuais.

\section{Concepções de ciclo que deformam}

As expectativas quanto à organização da escola em ciclos nem sempre são coincidentes, as experiências vêm sendo bastante variadas e até desencontradas. Estão sendo implantados ciclos que não passam de amontoados de séries, ciclos de progressão continuada, ciclos de competências, de alfabetização - por exemplo os CBAs -, como poderíamos ter ciclos de "matematização" ou do domínio contínuo de quaisquer 
outros conteúdos, habilidades e competências, ciclos de ensino-aprendizagem das disciplinas e até ciclos do antigo primário e do antigo ginásio. Na maioria dessas propostas a lógica seriada não é alterada, por vezes é reforçada, apenas o fluxo escolar pode ser amenizado com mecanismos de não reprovação, de aceleração ou de adiamento da retenção. Devemos perguntar-nos em que o perfil de professor muda nessas concepções de ciclo: elas formam ou deformam?

Nessas concepções de ciclo pouco há a mudar no perfil de professor, apenas algumas sensibilidades e habilidades novas que podem ser adquiridas em cursos de treinamento antes da implantação desses ciclos ou no processo. Se a concepção de educação básica e a lógica que estrutura os processos educativos na escola praticamente não são alteradas, o perfil de profissional será o mesmo e as habilidades e competências serão praticamente as mesmas com pequenos retoques no percurso. Aí tem sentido apenas um treinamento precedente. O que estou sugerindo é que há uma correspondência entre o profissional que queremos e formamos e a concepção de educação básica que a lógica da instituição escolar objetiva ou materializa. Se essa lógica e essa concepção se mantêm inalteradas ainda que falemos em ciclos, não há como pensar em outro profissional nem em outras propostas para sua formação. Pequenos retoques serão suficientes.

A história das reformas mostra essa correspondência quase mecânica entre a lógica estruturante dos sistemas escolares, a concepção de prática de educação básica, o perfil de professor e as ênfases em sua formação. Tivemos e temos inúmeras reformas e políticas que quase nada inovam na lógica estruturante do nosso sistema escolar, nem na concepção utilitarista e credencialista de ensino. Conseqüentemente, o perfil de professor e as propostas para sua formação pouco têm mudado nas últimas décadas, e podemos supor que pouco vão mudar apenas trocando série por ciclo. Que diferença há além do nome entre o antigo primário ( $1^{\mathrm{a}}$ a $\left.4^{\underline{a}}\right)$, e o que várias administrações hoje passaram a chamar de $1^{\circ}$ ciclo? Que diferença há entre o que por décadas foi identificado como ginásio $\left(5^{\underline{a}}\right.$ a $\left.8^{a}\right)$ e hoje passam a chamar de $2^{0}$ ciclo?

Nesses retoques, mais nominais do que reais, pouco há a pensar sobre a formação do profissional da organização por ciclos. Em realidade, essas administrações estão brincando de mudanças apenas trocando nomes. Os profissionais já perceberam esses truques pouco sérios. Agregar as séries do antigo primário em um ciclo e as séries do antigo ginásio em outro ciclo, em vez de contribuir para a construção de uma 
organização única de educação fundamental, que ainda não temos, pode significar um recuo à estrutura escolar preexistente à lei 5.692, de 1971. Um retrocesso lamentável. Uma irresponsabilidade histórica. Esses arranjos em ciclos em nada contribuirão para uma dívida antiga: formar um profissional único de educação fundamental; ao contrário, atrasará uma necessidade que é urgente, formar profissionais que tenham uma concepção única, uma formação orgânica com todo o percurso da educação fundamental. Essa divisão inconseqüente do direito à educação fundamental nas velhas divisões $-1^{\underline{a}}$ a $4^{\underline{a}}$ e $5^{\mathrm{a}}$ a $8^{\mathrm{a}}-$ continua norteando os PCNs. Tudo segue os velhos blocos pré-5.692/71: currículos para $1^{\text {a }}$ $4^{\text {a }}$ ( $1^{\circ}$ ciclo), currículos para $5^{a}-8^{a}\left(2^{\circ}\right.$ ciclo), formação de professores para as séries iniciais de um lado, e formação de professores para $5^{\underline{a}-8^{a}}$, e ensino médio, de outro. Que retrocesso lamentável.

Sabemos, e não há como ocultar, que essa agregação do antigo primário em $1^{\circ}$ ciclo e do antigo ginásio em $2^{\circ}$ ciclo tem uma motivação administrativa: municipalizar o antigo primário. Podemos ainda suspeitar que essa lamentável estrutura de ciclos termine por reduzir o direito popular à educação fundamental apenas a quatro séries, o dito $1^{\circ}$ ciclo. Há outra concepção oficial: implantar os ciclos, amontoados de séries, para acabar com a retenção, acelerar o fluxo, ou acabar com a defasagem idade-série em nome do respeito à diversidade de ritmos de aprendizagem, com processos mais leves de avaliação contínua, ao longo do ciclo. Essa visão de ciclos em nada mexe com as velhas concepções de educação e de seu profissional, antes as reforça e desqualifica. A pergunta que devemos nos fazer é se essa concepção de ciclos não desqualifica o papel de educador e a sua formação.

Nessa visão tão simplista de ciclo tem sentido estruturar algumas horas, para que os professores aprendam algumas competências "novas", para lidar com "ciclos"; para que aprendam como organizar turmas, como selecionar conteúdos do programa, como avaliar avanços, ritmos diferenciados, progressão contínua, como não reprovar mas acelerar os lentos, como agrupar por ritmos de aprendizagem, como normalizar o fluxo escolar, como enturmar, separar os lentos e defasados em turmas de aceleração... Se as mudanças não passam de retoques pontuais na veIha lógica seriada, terá sentido preparar antes, e será fácil e rápido preparar antes os professores para que estejam aptos a fazer essas correções de rumo em um sistema que continua inalterado em sua lógica e estrutura e na concepção de educação básica que o inspira. Podemos estar fazendo apenas uma caiação que oculte e adie os crônicos proble- 
mas, sem mudar o papel da escola e de seus profissionais, sem acrescentar nada novo a sua qualificação. Essa concepção de ciclo pode estar deformando e não formando um novo perfil de educador.

\section{Requalificando dimensões permanentes de nosso ofício}

Entretanto, há propostas pedagógicas assumidas por profissionais das redes municipais e estaduais e por suas administrações que tentam dar conta de outra concepção de organização da escola por ciclos, e se perguntam como questão fundamental que concepção de ciclos deve orientar a nova organização. Entendemos que essa concepção é inseparável do avanço do direito à educação básica, ou do direito ao pleno desenvolvimento de todos nós como seres humanos. Essa é a visão dominante na nova LBD (art. $2^{\circ}$ e $\left.22^{\circ}\right)$ e essa é a visão que nos orienta ao buscar um novo ordenamento, uma lógica estruturante do sistema escolar e da escola que dê conta dessa concepção de educação básica universal. Nesse quadro de preocupações, ciclo não é um amontoado ou conglomerado de séries, nem uma simples receita para facilitar o fluxo escolar, acabar com a reprovação e a retenção, não é uma seqüência de ritmos de aprendizagem. É mais do que isso. É uma procura, nada fácil, de organizar o trabalho, os tempos e espaços, os saberes, as experiências de socialização da maneira mais respeitosa para com as temporalidades do desenvolvimento humano. Desenvolver os educandos na especificidade de seus tempos-ciclos, da infância, da adolescência, da juventude ou da vida adulta. Pensamos em Ciclos de Formação ou de Desenvolvimento Humano.

As idades da vida, da formação humana passam a ser o eixo estruturante do pensar, planejar, intervir e fazer educativos, da organização das atividades, dos conhecimentos, dos valores, dos tempos e espaços. Trabalhar em um determinado tempo-ciclo da formação humana passa a ser o eixo identitário dos profissionais da educação básica e de seu trabalho coletivo e individual. O profissional passa a se ver como um educador, um pedagogo, um adulto que tenta dar conta dessas temporalidades do desenvolvimento humano com suas especificidades e exigências. A escola é vista como um encontro pedagogicamente pensado e organizado de gerações, de idades diferentes. Outra concepção de educação, outro profissional, logo, outros mecanismos para sua formação, outras dimensões a serem privilegiadas. 
Nesse quadro de propostas inovadoras, em que a superação da lógica seriada e a procura de uma nova lógica estruturante passam a ser um dos eixos inovadores, tem sentido colocarmos as questões que o tema aponta: que perfil de profissional vem se constituindo, formando na organização do trabalho pedagógico por Ciclos de Desenvolvimento Humano? Que traços, que saberes, que sensibilidades, que valores, que capacidades de escolha, que fazer pensado vão se perfilando como domínios desse profissional da educação básica? Como pensar pedagogicamente esses processos de formação? Essas questões acompanham todos os tempos de elaboração e implementação das propostas.

Uma das sensibilidades que vão se perfilando nos educadores que se empenham na organização da escola por Ciclos de Desenvolvimento Humano é em relação ao sentido da educação básica. As propostas pedagógicas que acompanho - antes de estarem preocupadas com a reprovação, com o fluxo escolar, com acabar com as séries - estão preocupadas em recuperar a concepção de educação básica como direito ao desenvolvimento humano, à realização humana. É a tradição que vem da paideia, da Renascença, do humanismo presente na llustração, radicalizado nas lutas pelos direitos sociais, pela emancipação humana e pela igualdade e diversidade. Nessa longa trajetória, foi se constituindo o perfil de pedagogo, educador, no que tem de mais permanente. Foi se perfilando historicamente o ofício de mestre-educador. Essas figuras que teriam de dar conta dos grandes questionamentos humanos.

As propostas pedagógicas que estruturam a escola em Ciclos de Desenvolvimento Humano se colocam como questão fundamental repensar a concepção e a prática de educação básica que estão presentes em nossa tradição e na estrutura seriada que as materializa. Essa tarefa é permanente. A organização por ciclos é apenas uma conseqüência da mudança na concepção e na prática de educação básica. O perfil de educador e sua formação são apenas uma conseqüência dessa mudança. Recuperando os vínculos entre concepção de educação básica, de ciclo e de educador, estaremos colocando a formação de educadores em patamares mais permanentes, aproximando-nos do que há de mais definidor no pensar e fazer dos professores. Fugimos de treinamentos pontuais e precedentes.

O educador que formamos tem tudo a ver com a concepção de educação básica que inspira os currículos, a didática, a organização escolar. A concepção de organização da escola em ciclos vai depender da concepção de educação básica que nos orienta. Penso que não podemos interpretar o art. 23 da nova LDB, que propõe a organização por ci- 
clos, sem referi-lo ao art. $22^{\circ}$ e aos art. $1^{\circ}$ e $2^{\circ}$, nos quais a LDB afirma sua concepção de educação. Pensar em organizar a escola em ciclos sem referi-los à concepção de educação básica tão afirmada na nova lei não tem sentido.

É verdade que a LDB tem inúmeras ambigüidades em relação à concepção de educação porque opta. Entretanto, não me parece exagero dizer que ela se afasta radicalmente da concepção utilitarista, mercantil, credencialista e propedêutica tão marcante na lei $n^{0} 5.692 / 71$. A nova LDB recupera uma concepção mais ampliada de educação. $O$ art. $1^{\circ}$ abre nosso olhar de educadores e vincula a educação à multiplicidade de processos formadores em que nos constituímos, socializamos, aprendemos, nos tornamos sociais, culturais, humanos. Retira a educação da estreiteza do mercado, do domínio de destrezas e habilidades para situá-la no campo da formação humana. Os art. $2^{\circ}$ e $22^{\circ}$ são ainda mais explícitos, afirmando que a finalidade da educação é o pleno desenvolvimento dos educandos. Situa como tarefa da educação desenvolver os educandos como seres humanos em sua plenitude, recuperando a velha tradição humanista que identifica educação com humanização. Coloca o cerne do direito à educação básica no campo dos direitos do ser humano a se desenvolver como humano. Uma visão bem distante da prática das últimas décadas, que reduziu o direito à educação a receber da escola as credenciais e competências demandadas pelo mercado seletivo. Preparar para a empregabilidade.

A nova LBD nos diz que os educandos têm direito a mais. Nesse algo a mais tem sentido pensar em Ciclos de Desenvolvimento Humano, em temporalidades da formação humana, ou em tentar organizar a escola, os conteúdos, os tempos e espaços, os rituais de avaliação, a organização do trabalho dos mestres e educandos para darem conta dos tempos, dos ciclos de desenvolvimento dos educandos. Insisto que essa concepção da LDB está distante da concepção estreita de ciclos reduzidos a amontoados de séries, ciclos de progressão, de conteúdos, ciclos de alfabetização, ciclos para facilitar o fluxo, para não reter etc. Essas concepções não dão conta da radicalidade em que a nova LDB e todos os humanismos pedagógicos situaram a função social e cultural da educação básica e o perfil de educador.

Sendo fiéis a esses humanismos pedagógicos, levando a organização por ciclos a essa radicalidade, entendemos as virtualidades formadoras para os professores que se engajarem nessa construção. Organizar a escola em Ciclos de Desenvolvimento Humano vai significando que todos repensemos nossa concepção de educação e repensemos o papel, o per- 
fil, a função social do educador. Significa repor nosso ofício em outros patamares, descobrirmo-nos profissionais do pleno desenvolvimento humano. Entendermos as temporalidades, os ciclos da formação humana, assumirmo-nos profissionais do desenvolvimento humano, requalificarmonos, recuperando dimensões permanentes em nosso ofício de mestres.

Participar desse processo é formador, é ressignificar pensamentos, valores, sentimentos, imaginários, auto-imagens. É redefinir competências, práticas, capacidades de fazer escolhas. É encontrar outro sentido para o próprio ofício de mestre e a própria existência humana.

É interessante acompanhar todo o processo de elaboração e implementação das propostas pedagógicas que tentam recuperar outra concepção de educação básica e tentam uma organização escolar que dê conta do desenvolvimento humano, de seus ciclos. Esse processo é concomitante a um movimento de confronto com pensamentos, valores, representações, culturas escolares e profissionais. É um confronto com a própria imagem de educadores. Há uma tensa desconstrução-construção de referências, de culturas. Há um tenso processo de desenvolvimento humano, social, cultural dos professores. Há uma formação concomitante. É freqüente ouvirmos de professores que participam de coletivos de profissionais de ciclo: não foi fácil, perdemos o chão, o tapete de nossa cultura seriada, mas nos fizemos outros, não somos os mesmos, não dá para voltar atrás. Somos outros e outras como professores e como pessoas.

Possivelmente este seja um dos produtos mais fortes dessas propostas pedagógicas, não pretendem mudanças pontuais, não têm por finalidade reprovar ou passar todo mundo, introduzir esta ou aquela temática nas grades curriculares, avaliar desta ou daquela maneira. Não é fácil, mas muitos profissionais pretendem como coletivos ir mais fundo: buscar um novo sentido ou reencontrar velhos sentidos no seu ofício e na função social e cultural da escola. Penso ser esta a visão mais radical de formação presente na nova LDB, na medida em que recoloca a educação nos processos de desenvolvimento e formação humana e propõe uma nova organização de escola para dar conta das especificidades de cada tempo-ciclo de desenvolvimento dos educandos. Essa visão mais radical da educação básica é o caminho para encontrar o sempre velho e sempre novo perfil e sentido do ofício de mestres. Estes têm o direito de ir às grandes questões que dão sentido a seu pensar e fazer. Questões que os requalificam porque são as mesmas que o ser humano sempre se colocou, que procurou responder, que aprendeu a responder, ou para as quais não encontramos respostas prontas. 


\section{Notas}

1. Embora o autor tenha feito uma distinção de genero em todas as ocorrências de palavras como: educador, professor, administrador, supervisor, etc., a revisora da revista optou por uniformizá-los no masculino, conforme o padrão utilizado por todos os outros autores.

\section{Human Development Cycles and educators upbringing.}

The cycles aren't an isolated proposal any longer, the new LDB legitimated them and they are being adopted by many school nets. This text asks itself about the kind of professional that is being formed in this such kind of pedagogical work organisation. The reflection is structured in 2 parts. The first reflects on the upbringing of thinking over the conceptions and formation practices that take place in the implementation of cycles. The $2^{\text {nd }}$ part reflects about the virtualities that form the whole process of not building the structure centres in the temporalities or Human Development Cycles. 